\title{
Agricultura, muntanyes i... La percepció de la província de Lleida per part dels estudiants universitaris catalans*
}

\author{
Daniel Paül i Agustí \\ Universitat de Lleida. Departament de Geografia i Sociologia \\ dpaul@geosoc.udl.cat
}

Recepció: juliol de 2014

Acceptació: juny de 2015

\section{Resum}

La imatge que es té d'una ciutat o d'un territori és important. Si és coneguda, el territori resultarà més proper. Si és desconeguda, poden existir condicionants importants per desenvolupar-hi certes activitats. L'estudi que es presenta mostra les diferents visions que poden existir de la província de Lleida. Sobre la base d'un qüestionari realitzat a 170 estudiants universitaris catalans es vol establir els elements que de forma més habitual s'associen amb la província. Els resultats mostren com l'agricultura constitueix l'element fonamental de la imatge genèrica de la província. No obstant això, la situació canvia quan es demana concretar aquests aspectes en un mapa. En aquest cas, les capitals de comarca i els Pirineus passen a primer pla. Aquest fet mostra una contradicció entre la imatge general que els estudiants tenen de la província de Lleida i la concreció d'aquesta imatge.

Paraules clau: imatge del territori; percepció; identitat; Lleida; Catalunya.

Resumen. Agricultura, montañas y... La percepción del territorio de la provincia de Lleida por los estudiantes universitarios catalanes

La imagen que se tiene de una ciudad o de un territorio es importante. Si es conocida, el territorio resultará más cercano. Si es desconocida, pueden existir condicionantes importantes para el desarrollo de ciertas actividades. El estudio que se presenta muestra las distintas visiones que pueden existir de la provincia de Lleida. Sobre la base de un cuestionario realizado a 170 estudiantes universitarios catalanes se quiere establecer los elementos que de forma más habitual se asocian con la provincia. Los resultados muestran cómo la agricultura constituye el elemento fundamental de la imagen genérica de la provincia. No obstante, la situación cambia cuando se pide concretar estos aspectos en un mapa. En este caso, las capitales de comarca y los Pirineos pasan a primer plano. Este hecho muestra una contradicción entre la imagen general que los estudiantes tienen de la provincia de Lleida y la concreción de esta imagen.

Palabras clave: imagen del territorio; percepción; identidad; Lleida; Catalunya.

* El present article s’integra dins del projecte finançat pel Pla Nacional de $\mathrm{I}+\mathrm{D}+\mathrm{I}$ «Competitividad e innovación en el desarrollo territorial: definiendo las bases de un nuevo modelo socio-económico para una España post-crisis» (CSO2012-39373-C04-02). També ha estat possible gràcies al finançament del Grup de Recerca Consolidat «Territori i Societat» de la Generalitat de Catalunya (2014 SGR 973). 
Résumé. Agriculture, montagnes et ... La perception de la province de Lleida par les étudiants universitaires catalans

L'image que nous pouvons avoir d'une ville ou d'une région est importante. Si elle est connue, le territoire sera plus proche. Si elle est inconnue, il peut exister des contraintes au développement de certaines activités. L'étude que nous présentons montre les différentes images qui existent de la province de Lleida. Basée sur un questionnaire réalisé auprès de 170 étudiants universitaires catalans, l'étude veut établir les éléments les plus communément associés à la province. Les résultats montrent comment l'agriculture est l'élément fondamental de l'image générique de la province. Toutefois, la situation change lorsqu'on demande de montrer ces éléments sur une carte. Dans ce cas, les capitales régionales et les Pyrénées passent devant. Cela montre une contradiction entre l'image générale que les étudiants ont de la province de Lleida et la concrétion de cette image.

Mots-clés: image du territoire; perception; identité; Lleida; Catalogne.

Abstract. Agriculture, mountains and... The perception of the province of Lleida by Catalan university students

The image of a city or a territory is important. If it is known, the territory will become closer. If it is unknown, important obstacles can exist for the development of certain activities. This paper examines the existing views on the province of Lleida. Based on a survey of 170 Catalan university students, we attempt to determine the elements that are regularly associated to the province. The results show that agriculture constitutes the main element in the generic image of the province. However, the situation changes when we asked students to specify these aspects on a map. In this case, the capitals of the region and the Pyrenees come to the fore, thus revealing a contradiction between the general image that students have of the province of Lleida and the realization of this image.

Keywords: image of the territory; perception; identity; Lleida; Catalonia.

\author{
Sumari \\ 1. Introducció $\quad 5$. Els elements representatius de \\ 2. La importància de la imatge del \\ territori \\ la província: una presència important \\ dels espais dels Pirineus \\ 3. Metodologia \\ 6. El mapa de la província \\ 7. Un coneixement fragmentat \\ de la província \\ Referències bibliogràfiques
}

\title{
1. Introducció
}

Dins del context de Catalunya, la província de Lleida presenta una sèrie de característiques diferenciades de les altres tres províncies catalanes (Barcelona, Tarragona i Girona). Així, tot i ser la província més extensa de Catalunya, amb $12.150 \mathrm{~km}^{2}$ (38\% de la superfície de Catalunya) també és el territori on hi habita menys població, 437.738 habitants el 2014 (un 5,8\% de la població catalana). 


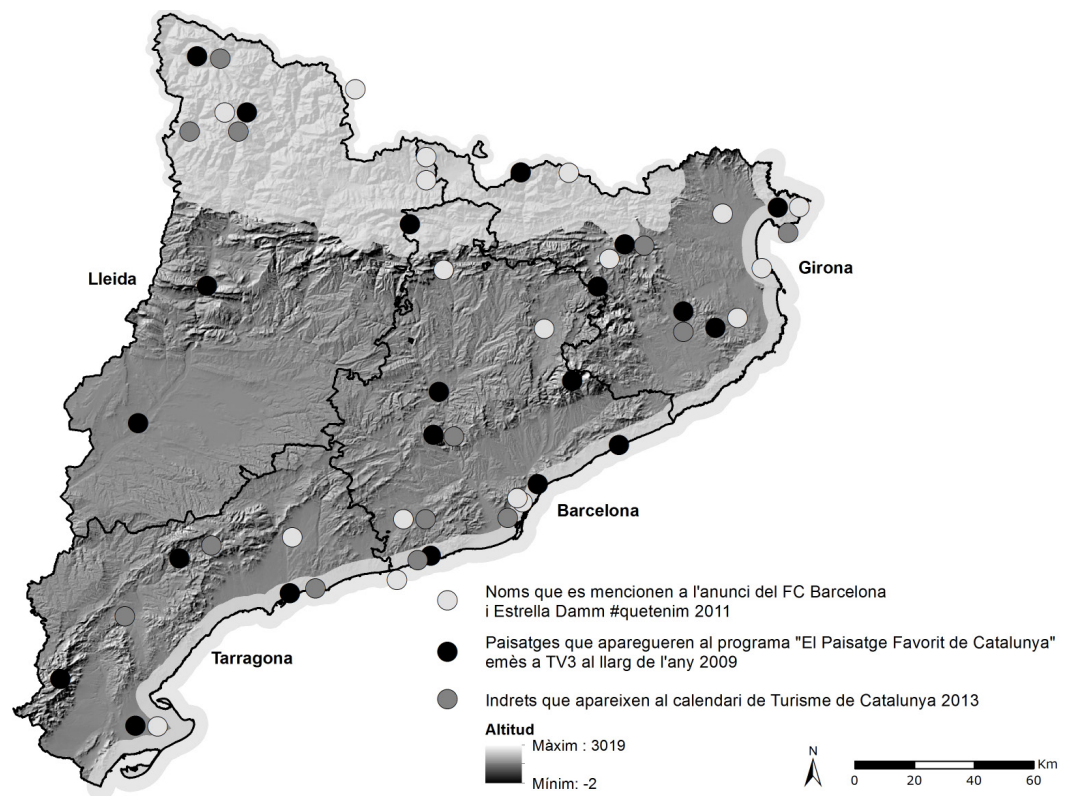

Mapa 1. Atractius catalans mencionats per diverses fonts.

Font: Iban Tarrés - Universitat de Lleida. Ombrejat del Model Digital del Terreny (MDT) i altimetria, ICGC.

De fet, la xarxa urbana de la província la formen ciutats poc poblades. Només Lleida supera els cent mil habitants (139.809 habitants l'any 2014). La segona ciutat en volum de població de la província, i la tercera, Tàrrega i Balaguer, no arriben als 17.000 habitants. Es tracta, igualment, d'una província majoritàriament agrícola, que concentra el 50\% de la SAU (superfície agrària útil) de Catalunya i el 32\% dels treballadors en el sector primari. Aquests tres elements, gran extensió del territori, poca població i teixit econòmic amb una presència del sector agrícola superior a l'habitual a Catalunya singularitzen la província.

Ara bé, més enllà de les diferències obtingudes a partir de les dades socioeconòmiques, la imatge que es projecta de la província de Lleida acostuma a ser més fragmentada que la de la resta de Catalunya. A mode d'exemple d'aquestes diferències podem mencionar tres iniciatives relativament recents, dispars en origen i objectius però que tenen en comú la voluntat de tractat el conjunt del territori. La primera és la sèrie de TV3 El paisatge favorit de Catalunya (2009), que pretenia donar a conèixer els territoris més valorats per diverses personalitats. La segona és un anunci d'una empresa privada, Estrella Damm, \#quetenim (2011). La tercera, en canvi, es dirigia al turisme i estava editada per Turisme de Catalunya (2013). Malgrat les diverses procedències, en tots tres casos podem observar una distribució similar dels elements representats.

Dels quaranta-sis atractius que apareixen en aquestes fonts, mostrats en el mapa 1, quinze corresponen a la província de Girona $(32,6 \%)$, catorze a 
la de Barcelona (32,6\%), nou a la de Tarragona $(19,6 \%)$ i vuit a la de Lleida $(17,4 \%)^{1}$. És més, d'aquests vuit atractius esmentats a la província de Lleida, sis són a l'Alt Pirineu. De fet, només la referència de TV3 planteja l'existència d'elements atractius a la Plana de Lleida.

Aquesta situació no és nova. Com apuntava Mendizàbal fa més de dues dècades en la seva proposta de model gràfic de Catalunya (imatge 1), en termes generals al país sobresortien cinc ciutats que s'apuntava que estructuraven el territori català (Barcelona, Tarragona, Girona, Manresa i Lleida) i dues línies de relleu (els Prepirineus i la Serralada Prelitoral). A partir d'aquesta base, Catalunya es dividia en dos espais, la "Catalunya del silenci» $\mathrm{i}$ la "Catalunya del soroll», acompanyades d'alguns espais aillats que formarien la "Catalunya de l'oci». Així mateix, Mendizàbal concloïa que:

El model espacial de Catalunya proposat en aquest treball vol mostrar una situació dicotòmica que té una certa lògica: la desigual distribució de la població, de les seves múltiples activitats i de les infraestructures fa que hi hagi una part de Catalunya on sembla que no hi passa res perquè sembla que no hi ha res. (Mendizàbal, 1993: 108)

La coincidència entre els dos mapes, un basat en criteris bàsicament publicitaris i el segon elaborat amb una visió més d'expert, ens porta a plantejar fins a quin punt estava difosa aquesta imatge que associa la província de Lleida amb la "Catalunya silenciosa» de Mendizàbal. La coincidència era simplement casual o la imatge del territori que se n'extreia es trobava àmpliament difosa en la societat? Per respondre a aquesta pregunta es va plantejar un qüestionari, adreçat als estudiants catalans, en què s'analitzava la imatge de la província de Lleida.

\section{La importància de la imatge del territori}

El grau de coneixement i de reconeixement d'una ciutat o territori resulta fonamental per al seu bon desenvolupament. D'aquest reconeixement poden dependre, en bona mesura, aspectes molts diversos. Per exemple, si una ciutat no és coneguda, la seva universitat pot atreure menys estudiants; pot ser més difícil que s'hi instal.lin empreses; pot no resultar atractiva per a nous habitants. En canvi, si és coneguda i reconeguda, pot atreure més turistes o pot difondre millor les seves activitats.

La creació i la gestió de la imatge d'un territori, però, no són facils. La imatge d'un determinat indret dependrà, en bona mesura, de la capacitat de cada espai per comunicar i fer arribar al públic potencial les percepcions existents sobre aquell espai i sobre les persones que hi viuen (Pritchard, 2000; Santos i Buzinde, 2006). Un element complex, ja que tot sovint l'origen d'aquestes imatges és desconegut i no s'ajusta completament a la realitat:

1. Els dos atractius mencionats a la Cerdanya no s'han inclòs en cap província. 


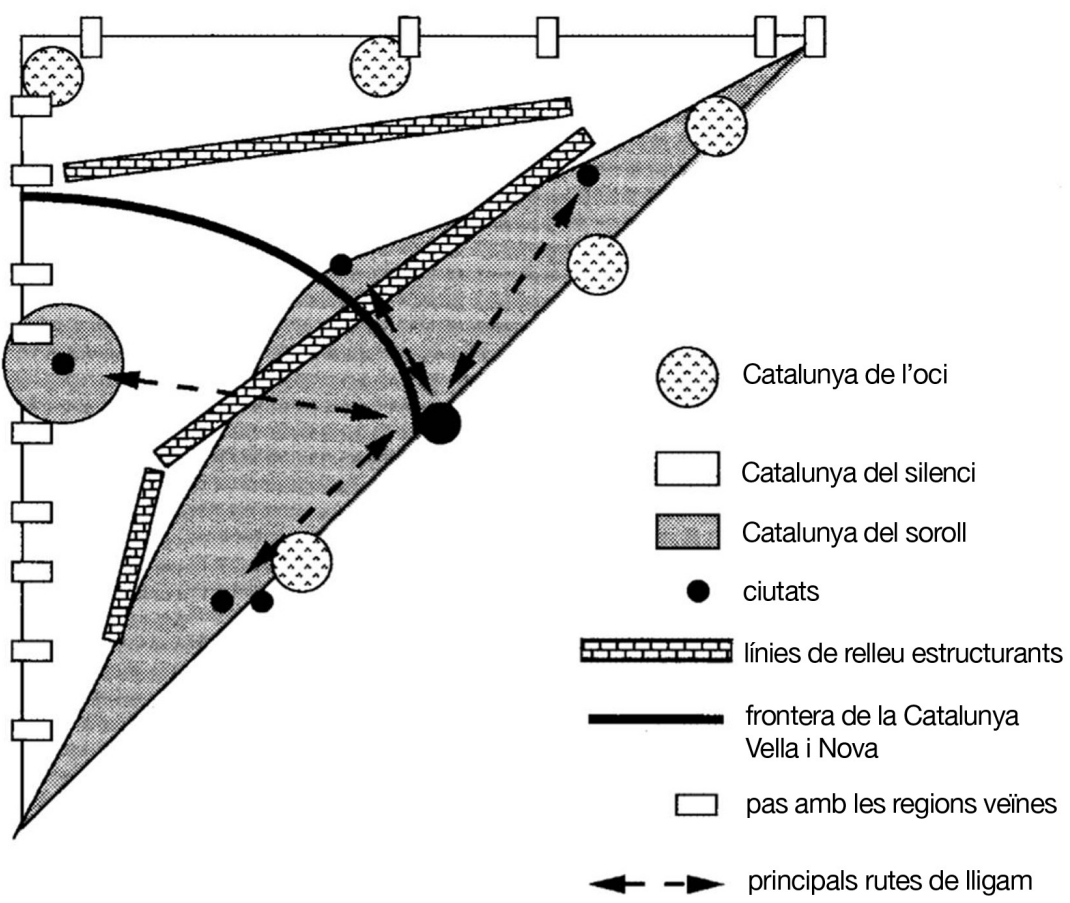

Imatge 1. Un model gràfic de Catalunya.

Font: Mendizàbal (1993: 118).

Molt sovint, aquestes imatges romanen estereotipades per una bona raó. No som capaços de captar tota la diversitat del món i per tant tendim a confiar en generalitzacions. Les llacunes en el nostre coneixement, grans i petites, estan plenes d'imaginació i exageracions, per crear una imatge completa mental que anhelem. El resultat són classificacions estereotipades d'altres regions i els seus habitants, que constitueixen una il.lusòria sensació de complet enteniment, d'ordre i d'estabilitat —una percepció tranquil.litzadora de tenir-ho tot sota control. (Hottola, 2012: 50)

En la creació d'imatges intervenen un nombre important de factors gràcies als quals la imatge del territori es pot analitzar com «un sistema d'idees i judicis, organitzats i autònoms, que serveixen per descriure, explicar, interpretar i justificar la situació d'un grup o un col-lectiu en l'espai» (Gilbert, 1986: 60). Aquest aspecte, com ja apuntava Tuan (1977), no suposa una limitació ja que l'intent d'analitzar els fenòmens humans únicament des d'un punt de vista purament quantitatiu podria portar a perdre aspectes importants del comportament humà.

La justificació del pes de les diverses relacions en el moment de definir la imatge d'un territori s'inscriu en un procés de producció basat en les estructu- 
res socials (Cloke et al., 1999). En aquest sentit, existirien dues grans teories pel que fa a la justificació de la producció de la imatge. Una basada en la separació del món social en dos universos (real i imaginari) i una segona basada en una concepció en què la imatge intervindria en el desenvolupament del conjunt de formes socials. En la present recerca hem optat per seguir la visió de Chivallon (2008) i privilegiar aquesta segona visió.

La concreció d'aquestes imatges percebudes i la seva representació ha estat objecte de diversos estudis. En aquest sentit, una bona aproximació és la que proposa Dupré (2006: 54) qui, basant-se en Gumuchian (1991: 67), assenyala que «el terme percepció ens remet als mecanismes perceptius $\mathrm{i}$ als fenòmens cognitius que fan possible l'elaboració de les imatges, tot estructurant-se posteriorment en representacions». Així, «les percepcions serien la funció segons la qual l'esperit representa els objectes presents mentre que la representació permet evocar objectes, fins i tot quan aquests no són directament perceptibles» (Auray et al., 1994: 13-14). La fixació en l'imaginari col-lectiu d'una determinada imatge dependrà, per tant, de diversos filtres que es poden concretar en aspectes com ara un fet, una vivència, un espai, etc., sense que això suposi una experiència de coneixement directe (De Alba, 2009).

En aquest sentit, la comunicació i les representacions socials resultaran fonamentals. Ambdues enteses en un sentit ampli: des de mitjans de comunicació a narracions; des d'experiències pròpies a visites d'amics; des de l'educació rebuda a les pel-lícules visionades. En altres paraules, les imatges donen significats que són interpretats segons com siguin percebuts, però condicionats pels «filtres» psicològics, antropològics, geogràfics, culturals i familiars de cadascú (Mackay i Fesenmaier, 1997; Musset, 2010).

La comunicació es caracteritza, en línies generals i segons la definició de Cameron (1968), per l'existència d'un emissor, un mitjà i un receptor. Altres autors (Knez i Wright, 1970) van aprofundir en aquest estudi i van apuntar que, a la llarga, la comunicació actuava com un cercle, en què el receptor acabava actuant també d'emissor.

Ara bé, el model més habitual de referència en la temàtica és el proposat per Wilbur Schramm l'any 1954 (mostrat en el gràfic 1). Segons aquest model (citat per Greffe, 1999), la comunicació implica diversos elements: identificar l'emissor i el receptor, la codificació necessària per transmetre el missatge, el missatge en ell mateix, la descodificació com a comprensió efectiva per part del receptor, els camps d'experiències passades de les parts implicades, l'esquema de referència i la retroacció o percepció per part de l'emissor de com el receptor ha rebut el missatge.

En la present recerca ens centrarem a analitzar únicament un dels integrants de la comunicació: el receptor i els coneixements que té dels espais de la província de Lleida. No hem de passar per alt que la imatge reprodueix símbols amb un significat que ha estat construït i difós socialment. Són, per tant, percepcions individuals, introspeccions subjectives construïdes en la ment (Galí i Donaire, 2005). Una de les visions més habitualment acceptades en aquest camp és la que apunta que la imatge es dividiria en diferents compo- 


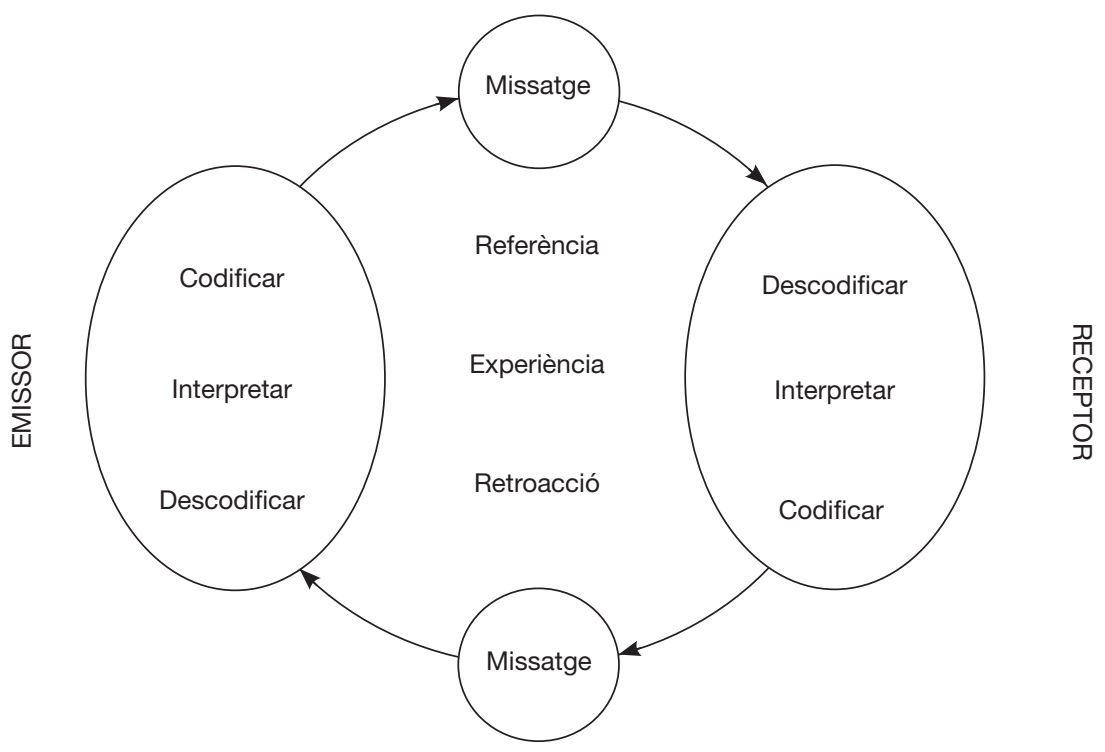

Gràfic 1. Model de Schramm.

Font: elaboració pròpia a partir de Greffe (1999).

nents cognitius (de coneixement) i afectius (de sentiments) (Smith, 2005). Més recentment, el gruix de les recerques han començat a interpretar la imatge com una percepció (Antrop i Van Eetvelde, 2000).

L'estudi de la imatge és, per tant, un element complex, ateses les múltiples facetes immaterials que entren en joc. La principal dificultat radica en el fet que les imatges no parlen per si soles, sinó que cal parlar d'elles. Segons la teoria de Lerivray (1975), actualitzada per Poutet (1995), es considera que en gran mesura la imatge actual d'una ciutat és herència directa dels ideals romàntics creats al segle XIX. Altres autors (Martínez, 1996; Miossec, 1977) consideren que la construcció de la imatge també depèn d'un cert procés de transformació. A tall d'exemple, Smith (2005) ha estudiat l'evolució de la imatge de Barcelona partint de la idea que està formada per significats relacionats amb el medi urbà, els quals poden ser alterats si s'encoratja els destinataris a extreure'n actituds positives. Ara bé, on hi ha unanimitat és en la consideració que la imatge de la ciutat és una construcció social (Ledrut, 1973; Marchand, 2005).

Aquest conjunt de factors dificulten tant l'ús com una lectura facil de les imatges per part de la geografia. Ara bé, si «la Geografia, com a ciència social, no s'ocupa (únicament) del món tal com és, sinó també del món tal com és percebut, viscut i practicat” (Staszak, 2014: 597), l'anàlisi de la percepció que els estudiants catalans tenen de la província de Lleida pot aportar una informació rellevant. En aquest sentit, el treball s'inscriu en la línia d'altres estudis 
on s'apunta que la imatge geogràfica, tot i que cal manejar-la amb prudència (Gumuchian, 1991), pot resultar fonamental per entendre les diverses relacions existents entre societats i territoris (Berdoulay, 1985; Castree, 2001; Debarbieux i Vanier, 2001; Di Méo i Buléon, 2005; Massey, 2005).

En conseqüència, en el present treball no entrarem en definicions tancades, sinó que ens centrarem a oferir alguns exemples de l'estudi portat a terme, amb la intenció d'obtenir una aproximació a la imatge que els estudiants universitaris catalans tenen de l'àrea d'estudi a partir de dos grans punts de vista. En primer lloc, com un element d'un discurs propi de la disciplina, però també com un fenomen que pot condicionar la vida social (Aldhuy, 2004; Sassen, 2001). L'objectiu és analitzar els elements que serveixen per reforçar la identitat col-lectiva (Avendaño Arias, 2014) i per entendre les particularitats dels diversos territoris. Uns aspectes, tots ells, que poden tenir influència en l'ordenació del territori, l'estudi dels fluxos o la creació de xarxes (Bédard et al., 2011; Berque, 1994; Dupré, 2006).

Un últim aspecte de la recerca que cal ressaltar és que part de la novetat de l'anàlisi radica també en l'àmbit d'estudi, la província. Com han apuntat diversos autors, aquests tipus d'estudis han tendit a basar-se, ja des dels estudis més clàssics (Lynch, 1960), en l'anàlisi dels espais urbans (Herrero Frabegat, 2008; Mc Kenna et al., 2008; Somoza Medina, 2006; Vara Muñoz, 2008), generalment un barri o un espai encara més acotat. Malgrat alguns estudis anteriors, com per exemple el de Pinheiro (1998), referits a la percepció del conjunt del món, o els d' Andressen (1997) referits a Àsia, no ha estat fins als darrers anys que han començat a proliferar estudis que analitzen àmbits no urbans, com els boscos (Dupré, 2006: 54), la percepció dels pescadors d'un llac (Mc Kenna et al., 2008), el litoral (Gueben-Venière, 2011) o determinats països com Brasil (Arruda i Ulup, 2007), Mèxic (Guerrero, 2007) o Austràlia (Gökten i Südas, 2014). Unes experiències, però, que resten limitades. Aquesta escassa atenció a l'àmbit no urbà ha generat crítiques entre diversos autors. S'assenyala que una visió com aquesta equivaldria a considerar els territoris no urbans com «un no-lloc o un no-paisatge, certament territoris sense legitimitat i sense significació» (Bédard et al., 2011: 5). Per aquest motiu s'han començat a desenvolupar anàlisis més àmplies que permeten mostrar la pluralitat d'actors i de funcions dels diversos territoris. Aquest fet suposa un canvi, no només d'escala. Així, els mapes urbans tendeixen a centrar-se en espais de circulació, viscuts i amb experiència pràctica. En canvi, els mapes d'àrees més àmplies organitzen coneixement $\mathrm{i}$ afectes sobre una àrea de la qual no hi ha una experiència directa (Arruda i Ulup, 2007). És en aquesta nova línia on s’inclou aquest treball.

\section{Metodologia}

Per obtenir les dades que permetessin representar la imatge de la província de Lleida es va plantejar un qüestionari que van respondre 170 estudiants universitaris catalans, residents a Lleida ciutat, a la província i a la resta del territori 
català2. Tal com recull Roulier (2013), els estudiants universitaris han estat un públic habitual en aquesta tipologia de recerques, amb resultats satisfactoris (Dupré, 2006; Guerrero, 2007). Malgrat tot, els resultats obtinguts han de ser presos com a indicatius i exploratoris d'unes tendències generals. En aquest sentit, «els resultats no s'haurien de llegir com un seguit de coneixements individuals, sinó com un coneixement comú d'un grup social identificat per aquesta característica comuna» (Gueben-Venière, 2011: 4).

La voluntat d'obtenir respostes com més àmplies millores va concretar en el disseny d'un qüestionari obert, amb un nombre voluntàriament restringit de preguntes. El qüestionari era anònim i només es demanava la data de naixement, el lloc de residència familiar i el lloc de residència durant el curs. Amb aquestes dades es pretenia obtenir un perfil dels estudiants ${ }^{3}$ i especialment, detectar possibles lleidatans residents en altres províncies. Un aspecte que hauria pogut distorsionar la mostra.

El suport elegit per realitzar el qüestionari va ser el paper. Un mitjà que permet recollir la informació de forma relativament anònima, àgil i diversa (text, imatges, comentaris). Ara bé, el paper també pot presentar alguns problemes, com per exemple un nombre de respostes baix en alguns dels participants, algunes respostes parcials o certa desorientació respecte als elements o les preguntes formulades en part dels participants. Per evitar tant com fos possible aquesta situació, abans de realitzar el qüestionari es feia una breu explicació sobre la metodologia $i$, per exemple, es deixava clar que l'àmbit de referència era la província de Lleida, no la ciutat. Per tal de no condicionar els resultats només un cop acabat el qüestionari s'explicaven els objectius de la recerca. Cada pregunta es responia en un full diferent, que es retirava abans d'entregar el següent, fet que evita possibles modificacions de les respostes. L'ordre de les preguntes també estava plantejat per no condicionar les respostes ${ }^{4}$.

La primera pregunta que s'havia de respondre era «Escriu diverses paraules que personalment et serveixin per definir la província de Lleida». A partir

2. Concretament, els grups entrevistats van ser els següents: a Lleida 49 qüestionaris a «Societat, família i escola», 1r del Grau d'Educació Primària, Universitat de Lleida, professora Mariona Lladonosa (12 de novembre de 2012); a Tarragona, 36 qüestionaris a «Fonaments d'Anàlisi Geogràfica», 1r curs del Grau de Geografia i de Turisme, Universitat Rovira i Virgili, professor Òscar Saladié (18 de desembre 2012); a Girona, 26 qüestionaris a «Dinàmiques i gestió dels espais urbans i rurals», 3r del Grau de Geografia, Universitat de Girona, professor Joan Vicente (21 de novembre de 2012); a Barcelona, 59 qüestionaris a "Geografia Turística Mundial», 2n del Grau de Turisme, Escola Universitària Mediterrani, professor Daniel Paül (13 de desembre de 2012). Volem agrair la participació tant dels alumnes com dels professors.

3. Tot i tenir aquestes dades, els resultats no mostraven diferències significatives en funció de l'edat, per la qual cosa no hem incorporat informació referent a aquesta variable en el present article.

4. En una sèrie de proves realitzades amb anterioritat a les de l'estudi es va intentar alterar l'ordre de les preguntes. El resultat era que la visió del mapa condicionava les respostes de la pregunta sobre termes que definissin la província; la majoria de respostes passaven a ser llavors topònims, fet que empobria la mostra. 
d'aquest enunciat, els estudiants havien d'escriure un llistat de termes relacionats amb la província de Lleida. No hi havia límit en el nombre de termes. Voluntàriament no es concretava la naturalesa d'aquestes «paraules». D'aquesta manera es pretenia que els estudiants tinguessin llibertat total per apuntar les respostes més adients, sense condicionar-los amb una llista prèvia de possibles temes (com hauria pogut ser preguntar per temes d'hidrografia, relleu, població o monuments). Naturalment, aquesta llibertat suposa que les dades obtingudes no siguin estadísticament representatives. Per aquest motiu, l'organització de les respostes s'ha basat en el procés de rànquing per valorar la inclusió o l'exclusió dels resultats.

La segona pregunta es basava en un mapa i es desdoblava en dos blocs: «Localitza entre 5 i 10 de les ciutats més importants de la província» i «Localitza entre 5 i 10 dels elements més representatius del conjunt del territori». Els dos blocs es responien sobre el mateix mapa mut de la província de Lleida i buscava que es concretessin les idees més generals demanades a la primera pregunta. Es tracta, per tant, d'una anàlisi quantitativa, basada en els raonaments subjectius i inductius amb el menor nombre d'a priori possible i amb el marc territorial, en el nostre cas la província de Lleida, com a únic marc predefinit (una metodologia ja desenvolupada per altres autors, com per exemple Gueben-Venière, 2011). Amb aquesta metodologia es redueixen les distorsions del dibuix i es facilita l'anàlisi dels resultats.

\section{Els conceptes associats a la província de Lleida: una província agrícola}

A partir del buidat de les dades es van obtenir 1.020 respostes, corresponents a 284 elements diferents. Els estudiants a la UdG van ser els qui van oferir més respostes per alumne $(7,8)$, mentre que els estudiants de Barcelona, els qui menys $(4,6)$. Curiosament, quan s'analitza el nombre absolut d'atractius diferents esmentats, els papers s'inverteixen. Els estudiants de Barcelona eren els qui en mencionaven més de diferents (116), mentre que els de Girona, els qui en mencionaven menys (87). Recordem, en aquest punt, que les respostes que podia oferir cada estudiant eren múltiples i lliures.

Dels 284 elements mencionats pel conjunt d'alumnes, només divuit van ser mencionats per més de deu persones (taula 1). Per tant, a partir de les dades obtingudes es poden observar unes respostes que s'aproximen a la noció de llarga cua. Aquest terme, procedent majoritàriament de l'àmbit turístic, s'utilitza per descriure la coincidència de la majoria dels turistes a visitar un nombre limitat d'elements patrimonials de les ciutats que visiten (Donaire i Galí, 2011). Diversos autors han treballat aquest concepte. Per exemple, Pan i Lii (2011) mostren com la imatge textual de Xina es concentra en uns pocs termes (Xi'an, Beijing, Gran Muralla). Un cop superades aquestes localitzacions freqüents, la diversitat de llocs creix i els nous conceptes es diversifiquen. Aquesta situació apareix en l'estudi elaborat. Hi ha un nombre limitat d'aspectes que s'associen majoritàriament a la província de Lleida, els quals formarien la imatge fonamental de la província, però un cop enumerats, la varietat augmenta. 
Taula 1. Trenta primeres respostes a la pregunta «Escriu diverses paraules que personalment et serveixin per definir la província de Lleida»

\begin{tabular}{|c|c|c|c|c|c|c|c|}
\hline & & UdG & URV & EUTM & UdL & Total & Sinònims \\
\hline 1 & Agricultura & 16 & 13 & 10 & 13 & 52 & $\begin{array}{l}\text { Agrícola, camps, conreus, cereals, } \\
\text { horta, presseguers }\end{array}$ \\
\hline 2 & Muntanya & 14 & 9 & 14 & 11 & 48 & Pirineus \\
\hline 3 & Plana & 16 & 4 & & 4 & 24 & \\
\hline 4 & Fred & 2 & 5 & 14 & 2 & 23 & \\
\hline 5 & Seu Vella & 5 & 2 & 5 & 11 & 23 & \\
\hline 6 & Natura & 2 & 1 & 13 & 4 & 20 & \\
\hline 7 & Boira & 5 & 4 & 7 & 1 & 17 & \\
\hline 8 & Esquí & 2 & 4 & 8 & 1 & 15 & $\mathrm{Neu}$ \\
\hline 9 & Fruita & 7 & 3 & 2 & 3 & 15 & \\
\hline 10 & Segre & 5 & 6 & 2 & 2 & 15 & Riu, aigua \\
\hline 11 & Esports d'aventura & 1 & 2 & 10 & 1 & 14 & \\
\hline 12 & Ramaderia & 5 & 5 & 1 & 3 & 14 & Granges, avícola, porcí \\
\hline 13 & $\mathrm{Sec}$ & 9 & 1 & 2 & 2 & 14 & \\
\hline 14 & Paisatge & 1 & & & 12 & 13 & \\
\hline 15 & Gran & & & 1 & 12 & 13 & Extensa \\
\hline 16 & Pobles & & 3 & 2 & 7 & 12 & Pobles petits, poblets \\
\hline 17 & Catalunya & & 6 & 4 & 1 & 11 & catalana, sentiment català \\
\hline 18 & Cultura & & 2 & & 8 & 10 & \\
\hline 19 & Diversa & 1 & & & 8 & 9 & \\
\hline 20 & Accent & 2 & 2 & 3 & 1 & 8 & Lleidatà \\
\hline 21 & Interior & 3 & & 3 & 1 & 7 & \\
\hline 22 & Pagesa & 3 & 1 & 2 & 1 & 7 & Gent pagesa \\
\hline 23 & Rural & 1 & 1 & 5 & & 7 & \\
\hline 24 & Calor & & 3 & 2 & 1 & 6 & \\
\hline 25 & Cargols & 1 & 1 & 3 & 1 & 6 & Aplec del caragol \\
\hline 26 & Turisme & & & & 6 & 6 & Interès turístic \\
\hline 27 & Frontera & & 4 & 1 & & 5 & \\
\hline 28 & Llunyà & 1 & 2 & 2 & & 5 & \\
\hline 29 & Tranquil·la & & & & 4 & 4 & \\
\hline 30 & Turisme rural & 1 & & 3 & & 4 & \\
\hline
\end{tabular}

Font: elaboració pròpia.

Com es pot veure, el principal terme al qual s’associa la província és «agricultura». La paraula «agricultura» és la més repetida en totes les províncies, excepte a Barcelona. En conjunt, el 30,6\% dels estudiants van donar aquesta resposta. Destaca especialment el fet que el 61,5\% dels gironins mencionessin aquest terme. El percentatge més baix s'assoleix a Barcelona (17\%). El nombre de mencions dels estudiants lleidatans està per sota de la mitjana $(26,5 \%)$.

Aquesta visió de la província com a espai agrícola es reforça si valorem que en 12è lloc apareix el terme "ramadera»; en el 16è, el de "fruita»; en el 22è, el 
terme «pagesa» i en el 23è, el terme més ampli de «rural». Les pautes de distribució d'aquests tres conceptes eren comparables a les del terme "agricultura». Sorprèn, no obstant això, la manca de referències a l'agroindústria, igualment important a la província.

En segona i tercera posició apareixen dos conceptes referents al relleu: «muntanya» $\mathrm{i}$ "plana». Ara bé, la intensitat de les mencions és clarament diferent. "Muntanya» és triada pel $28,2 \%$ dels estudiants, mentre que "plana» és triada per exactament la meitat. Novament a Girona sobresurten els dos termes: 53,9\% de respostes a «muntanya» i 61,5\% a "plana». Per al cas de la "muntanya», els resultats en les altres tres províncies són similars (entorn al 23\%). Pel que fa a "plana» són extremament variats: 11,1\% a Tarragona, un escàs $8,2 \%$ entre els mateixos lleidatans i un sorprenent $0 \%$ a Barcelona. Altrament dit, si no fos per les aportacions gironines aquest terme cauria a la 10a posició.

Si observem el relleu de la província de Lleida es pot veure que la proporció entre muntanya i plana no explica aquesta diferència. Per tant, en aquest punt, tenim una primera característica de la imatge de la província: un clar pes de la muntanya en l'imaginari col-lectiu. Aquesta dada contrasta amb el pes real de l'agricultura, molt més potent a la plana.

El quart concepte torna a presentar una dicotomia. «Fred» apareix en $4 \mathrm{a}$ posició, mentre calor ho fa en 24a. La imatge hivernal de la província guanya clarament a l'estiuenca, més encara si es reforça pel terme «boira» (7è) o «neuesquí» (8è). El que no deixa de ser curiós és que en tots quatre conceptes, els valors més baixos s'obtenen a Lleida, amb un màxim de dues mencions. Pels qui el «sofreixen», el clima no seria un element característic, sinó habitual.

La proximitat amb el territori que es descriu condiciona no només la resposta anterior, sinó també d'altres. Els conceptes "paisatge»5 (14a), "granextensa» (15a), «pobles» (16a), «cultura» (18a) i «diversa» (19a) només són significatius en les respostes dels propis lleidatans. Un cas extrem és el de «turisme» (26a), que només es menciona a la província de Lleida. Per la resta de Catalunya la província només té valor com a «turisme rural» (30a). Un element significatiu en un país turístic con Catalunya i que reforçaria la visió agrícola comentada anteriorment.

Més enllà dels conceptes descrits en la taula 1 , la resta d'aspectes de la província únicament apareixen de forma molt limitada. A mode d'exemple podem fer referència als elements que podríem englobar com a patrimonials. Si exceptuem la Seu Vella ( $5 \mathrm{a}$, gràcies sobretot a les respostes dels mateixos lleidatans) trobem molt pocs elements. A Girona apareixen les «trinxeres» i a Barcelona trobem una referència a l'«imperi Romà».

5. Referent al concepte "paisatge» cal fer un matís important. Si bé com a tal només es menciona a Lleida, també es mencionen en menor mesura altres conceptes que s'hi podrien associar: boscos $(2 \mathrm{~T}, 1 \mathrm{G})$, zones estepàries $(1 \mathrm{G})$, verda $(3 \mathrm{~L})$, escarpat $(1 \mathrm{G})$, llacs glacials (1G) o groga (1B). Utilitzem les abreviacions B per referir-nos als estudiants de la província de Barcelona, G per als de Girona, L per als de Lleida i T per als de Tarragona. 
Les referències a termes de producció econòmica també són limitades. Trobem a Girona les «cooperatives», la «indústria familiar» $\mathrm{i}$ «l'agroindústria». Només a Barcelona apareix una referència a la marca comercial bonÀrea (de la Corporació Alimentària de Guissona, la principal empresa de la província) i algunes referències a «els productes de la terra». A Lleida, trobem una menció referent a «l'oli».

Un altra resposta espontània rellevant és la inclusió de diverses referències a la inversa: és l'absència dels diversos elements el que els confereix singularitat. La majoria d'aquests termes són dels lleidatans mateixos, i transmeten un cert sentiment de greuge respecte d'altres territoris. Un bon exemple són les tres respostes obtingudes referents a «menyspreada per les altres províncies» $\mathrm{O}$ "poc tinguda present». Altres respostes ofertes pels mateixos lleidatans, una única vegada, han estat "poques oportunitats», «mal connectada» $\mathrm{i}$ «incomunicada». Els problemes de comunicació també són mencionats en respostes de Barcelona (2). Altres respostes en aquesta línia són "poc cosmopolita» (1B), «poc poblada» (1B-3B), "poc turisme» (1G), "pocs recursos» (1B), "poques ganes d'anar-hi» (1B) $\mathrm{i}$ «sense mar» (1B). En alguns casos, la interpretació també pot ser positiva, com per exemple en l'afirmació "poc contaminada" (1L).

Un aspecte que ens ha sorprès és la manca de referències a personatges famosos de les terres de Lleida. De fet, entre els 170 estudiants només apareix un nom propi, el de Marc Màrquez (dues vegades a Girona) ${ }^{6}$. No hi ha cap altra referència a artistes, polítics, periodistes, etc. nascuts o relacionats amb la zona.

Finalment, pel que fa a les referències als topònims, ens ha sorprès el baix nombre d'indrets que s'han mencionat de manera espontània. Si deixem de banda les referències als Pirineus i al Segre, incloses en la taula anterior, només dos topònims s'han mencionat més d'un cop: la Pica d'Estats (un cop a Barcelona i l'altra a Tarragona) i la Vall d'Aran (dos cops a Barcelona). La resta de topònims només ha aparegut un únic cop: les Borges Blanques $(T)$, Boumort $(G)$, el Parc d'Aigüestortes $(G)$, el Segrià (G), Sort (B) i Vielha (T). També hi ha hagut una referència a la Depressió Central $(\mathrm{T})$. Així mateix, també s'han mencionat uns pocs llocs clarament identificables, com la Fira de Tàrrega (T), la Festa del vi d'Artesa de Segre (T) i l'Aquelarre de Cervera (B). Igualment apareixen alguns grans equipaments d'oci, significativament tots ells mencionats a Tarragona: les discoteques Big Ben (a Golmès) i Waikiki (a Agramunt) i l'estació d'esquí de Boí Taüll (Vall de Boí).

\section{Els elements representatius de la província: una presència important dels espais dels Pirineus}

La segona de les preguntes demanava dibuixar sobre el mapa de la província les «ciutats» i els «elements representatius del territori». En total, es van obtenir

6. La coincidència de la data del qüestionari a Girona amb una victòria d'aquest pilot podria explicar aquesta coincidència. 
Taula 2. «Elements representatius del territori» mencionats en totes les províncies catalanes

\begin{tabular}{|c|c|c|c|c|c|c|}
\hline & & Girona & Tarragona & Barcelona & Lleida & total \\
\hline 1 & Lleida & 25 & 30 & 24 & 45 & 124 \\
\hline 2 & Vielha & 18 & 23 & 16 & 37 & 94 \\
\hline 3 & Sort & 19 & 21 & 17 & 26 & 83 \\
\hline 4 & Tremp & 19 & 13 & 12 & 21 & 65 \\
\hline 5 & Mollerussa & 5 & 11 & 10 & 34 & 60 \\
\hline 6 & Balaguer & 4 & 12 & 1 & 41 & 58 \\
\hline 7 & la Seu d'Urgell & 9 & 11 & 15 & 22 & 57 \\
\hline 8 & Vall d'Aran & 4 & 12 & 17 & 8 & 41 \\
\hline 9 & Tàrrega & 5 & 7 & 6 & 21 & 39 \\
\hline 10 & Segre & 13 & 5 & 6 & 13 & 37 \\
\hline & Cervera & 10 & 7 & 6 & 11 & 34 \\
\hline & Pirineus & 4 & 8 & 8 & 13 & 33 \\
\hline 13 & Aigüestortes & 11 & 3 & 10 & 5 & 29 \\
\hline 14 & les Borges Blanques & 2 & 10 & 2 & 14 & 28 \\
\hline 15 & el Pont de Suert & 9 & 3 & 4 & 8 & 24 \\
\hline 16 & la Noguera Pallaresa & 4 & 2 & 5 & 2 & 13 \\
\hline & la Noguera Ribagorçana & 5 & 3 & 2 & 2 & 12 \\
\hline & Solsona & 1 & 1 & 7 & 1 & 10 \\
\hline & Baqueira Beret & 5 & 1 & 1 & 3 & 10 \\
\hline & Alt Urgell & 2 & 1 & 3 & 1 & 7 \\
\hline
\end{tabular}

Font: elaboració pròpia.

1.180 respostes, que corresponen a un total de 123 elements. Com és habitual en aquest tipus d'estudis, la proximitat juga a favor del coneixement del territori. Així, els qui van aportar més referències van ser els residents a la província de Lleida (81), seguit, amb valors similars, pels de Barcelona (53), Tarragona (47) i Girona (41).

En la taula 2 observem com novament hi ha un nombre limitat d'elements que es repeteixen a les quatre províncies. Un fet destacat és que entre els nuclis urbans només es mencionen les capitals comarcals. Aquest aspecte coincideix amb recerques desenvolupades en altres contextos, com França. És habitual que els estudiants tendeixin a recórrer en un primer moment a records dels diversos manuals de geografia estudiats en l'etapa escolar, tot reproduint el llistat de comarques i capitals après a l'escola (Roulier, 2013). Aquest fet justificaria que en el llistat anterior apareguin totes les capitals de comarca.

La capital provincial, Lleida, destaca amb un $72,9 \%$ de les referències. La segueixen, a distància, Vielha $(52,3 \%)$, Sort $(48,8 \%)$ i Tremp $(38,2 \%)$. Totes tres ciutats situades als Pirineus i mencionades de forma més habitual que les ciutats de la plana, molt més poblades. Un element que cal fer ressaltar és el de Sort, on normalment la població anava acompanyada de la menció a la seva administració de loteria, «la Bruixa d'Or» (7G i 5T). Les ciutats del Pla apareixen a continuació: Mollerussa $(35,3 \%)$ és cinquena i Balaguer, històri- 
cament la segona ciutat de la província, apareix sisena $(34,1 \%)$, amb un fort desconeixement en les respostes donades a Barcelona (una única resposta).

A escala comarcal, només en trobem dues que es mencionin al conjunt de Catalunya: la Val d'Aran i l'Alt Urgell. El cas de la Val d'Aran és especialment rellevant perquè és l'única comarca lleidatana que situa tres elements en el llistat. A més de la comarca i la capital, també apareix l'estació d'esquí de Baqueira Beret.

Fora de les ciutats, destaquen alguns elements de la geografia física, com els rius Segre (mencionat pel 50\% dels gironins), la Noguera Pallaresa i la Noguera Ribagorçana. Els Pirineus també són especialment mencionats, així com el Parc d'Aigüestortes.

La resta d'elements ja no van ser mencionats a les quatre províncies. En el camp dels topònims urbans es fa referència a les tres províncies, de més a menys vegades, a la Pobla de Segur, Ponts i Alcarràs. En dues a Juneda, Llavorsí, Camarasa, Vallfogona de Balaguer, Agramunt, Bellpuig, Bellver de Cerdanya, Esterri d'Àneu, Guissona, Verdú, Boí i la Vall de Boín. Mencionats en una única província trobem trenta-nou altres nuclis.

Entre els topònims no urbans destaquen les referències a totes les comarques, per bé que la diferència entre les vint-i-una mencions de la Val d'Aran, comentades anteriorment, i l'única menció al Pallars Jussà és evident. També destaca el cas de la Cerdanya, mencionada un cop a Tarragona, quatre a Barcelona i un a Lleida. A la província de Girona, amb qui Lleida comparteix aquesta comarca dividida, no s'hi ha fet referència cap vegada. Quedaria clar que pels gironins, la Cerdanya no forma part de Lleida.

Altres topònims mencionats són els referents als parcs naturals. A més d'Aigüestortes, comentat anteriorment, també es menciona el Cadí-Moixeró (4B), curiosament, en la forma adoptada pel parc natural, no com a topònims diferenciats (el Cadí només s'ha mencionat una vegada, a Girona); un element que ens hauria de fer reflexionar sobre el poder de les «marques» per alterar els topònims tradicionals. Altres topònims mencionats són els referents al relleu, tots ells menys de cinc vegades, a excepció de la Plana de Lleida, mencionada nou vegades, totes elles a Girona. Completen la llista les referències del Montsec en tres províncies, en dues del Prepirineu i la Depressió Central, i en una de tretze altres topònims.

Deixant de banda els topònims, altres elements que apareixen en el llistat són els corresponents a les infraestructures. Apareix l'aeroport de Lleida-Alguaire (significativament només en quatre mencions a Lleida), l'Eix Transversal (2G, 1B), l'AP-2 (1B, 1T) i el túnel de Vielha (1G).

En els mapes també s'han fet algunes referències a l'activitat comercial de la província. Ara bé, significativament, les referències a l'agricultura han desaparegut. Només vuit persones han situat en el mapa els fruiters (4L, 2T,

7. Si suméssim els resultats de «Boí», «Vall de Boí» i «Boí-Taüll» també estarien mencionats en les quatre províncies (10 resultats). Com que es tractava, no obstant això, de topònims diversos, no hem considerat adient incloure'ls en aquest punt. 
$2 \mathrm{G})$. Això és un $0,5 \%$ dels estudiants. Una xifra clarament inferior al 30,6\% que assenyalàvem en la primera pregunta cap a una província agrícola. Això ens porta a apuntar cap a una imatge difusa de l'agricultura, que la població no sabria concretar territorialment. «L'oli» també apareix en aquest camp, però només a Lleida (9). Altres activitats citades són l'esquí (7L, 5T).

Pel que fa als personatges de la província, tampoc n'apareixen excessivament en aquest llistat. Repeteix el pilot Marc Màrquez (2G) i apareix el futbolista Carles Puyol (1G).

Finalment, també hem d'apuntar, com a nota curiosa, la localització en el mapa de disset topònims que no corresponen a la província. Destaquen algunes localitats i comarques certament limítrofes, com Montblanc (4B), Andorra $(3 \mathrm{~B})$, Puigcerdà $(3 \mathrm{~B})$, el Berguedà $(3 \mathrm{~B})$ i Berga $(2 \mathrm{~B})$, significativament totes elles mencionades des de Barcelona. Altres ja es troben més allunyades, com la Terra Alta (2B, 1G) i Gandesa (1B), el Montsant (3B), Alforja (1B) o els Rasos de Peguera (1G). Altres errors són més difícils d'explicar, com les quatre mencions al riu Ter (3T i 1B), al riu Ebre (1B, 1G), la referència a Ripoll (1B), al delta de l'Ebre (2B) o una sorprenent referència a Osca (1L).

\section{El mapa de la província}

Un cop analitzats els indrets mencionats pels alumnes catalans, hem categoritzat els diversos elements en funció de la comarca a la qual pertanyen. D'aquesta manera, hem sintetitzat els principals resultats de les 170 respostes. En els casos en què un mateix element es trobava en més d'una comarca, s'ha repartit la puntuació entre les diverses comarques on es podria situar (per exemple, els Pirineus o el canal Segarra-Garrigues). Aquesta informació s'ha elaborat per construir un cartograma amb els resultats de cada una de les províncies (mapa 2).

Com es pot observar, els resultats presenten diferències significatives si es compara amb el mapa de superfícies (al centre). En termes generals, les comarques de la plana, per on circula el gran eix de comunicació de l'A-2, surten clarament sobredimensionades. Aquest és el cas, molt especialment, del Pla d'Urgell. L'experiència dels estudiants, molts dels quals de ben segur han utilitzat aquesta via, pot explicar aquesta situació. Una situació que també es pot apreciar a la Vall d'Aran i, en el cas de Girona, a les comarques dels Pirineus en general.

En canvi, altres comarques pràcticament no surten en el mapa. Aquest és el cas especialment del Solsonès, que només és mencionat d'una manera significativa a Barcelona. Aquesta manca de referències ens portaria a apuntar a una manca de percepció de la comarca com a part de la província de Lleida. Un fet que es donaria fins i tot entre els mateixos lleidatans (només un estudiant lleidatà va incloure referències al Solsonès). Una situació similar, tot i que no tan marcada, es donaria a la Cerdanya, probablement més associada a les comarques gironines. De fet, en aquesta comarca es repeteix la mateixa situació que hem comentat anteriorment referent als conceptes: cap 

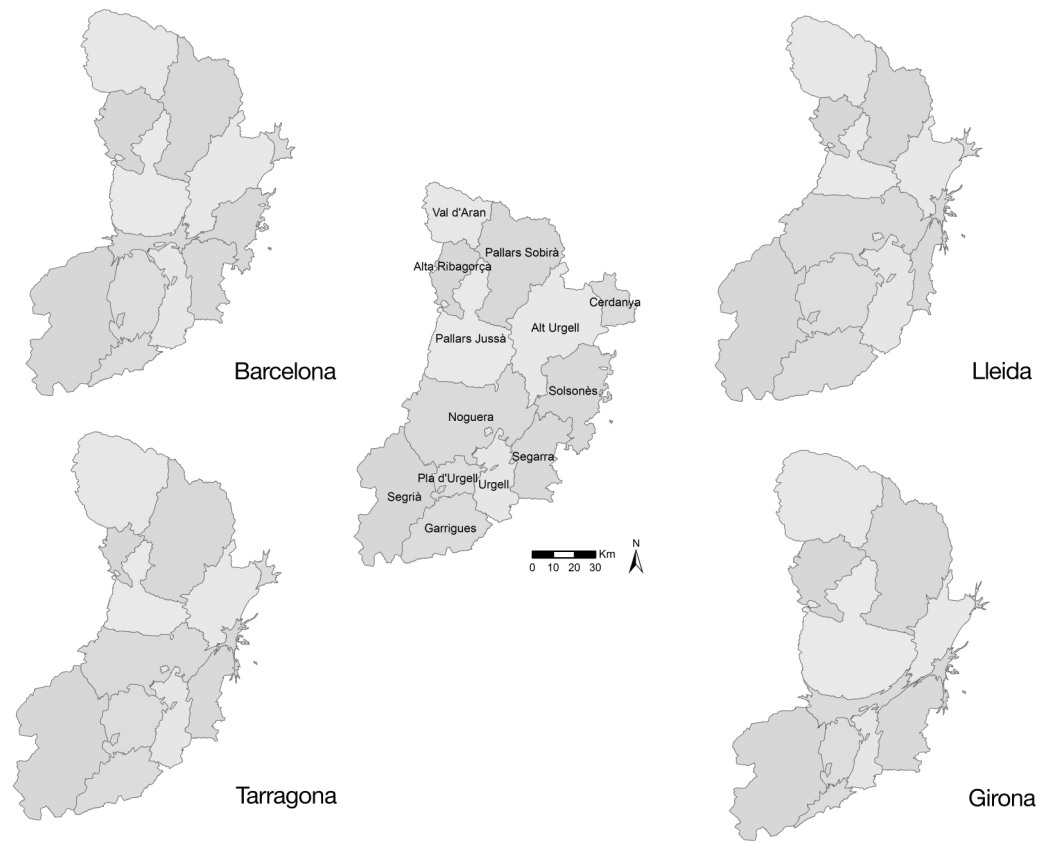

Mapa 2. Cartograma de la província de Lleida segons la visió dels estudiants de les diverses províncies catalanes.

Font: elaboració de les dades per part de l'autor. Cartografia: Iban Tarrés - Universitat de Lleida.

estudiant gironí ha fet referència a cap atractiu de la Cerdanya com a part de la província de Lleida.

Un altre aspecte destacat del mapa és el paper que es dóna a dues comarques que no són completament de la plana ni dels Pirineus: la Noguera i les Garrigues. La Noguera, significativament la comarca més extensa de Catalunya, pràcticament no apareix en les respostes donades a Barcelona i a Girona. En canvi, pels estudiants de Lleida, la comarca, i especialment la seva capital, sí que se situen en el mapa. Un patró molt similar es reprodueix a la comarca de les Garrigues. Les respostes que s'obtenen a la URV donen uns resultats similars als de Lleida. El veïnatge entre les dues províncies podria explicar aquest fet, que no hem observat en altres casos.

\section{Un coneixement fragmentat de la província}

A partir de les dades anteriors podem observar com la imatge que els estudiants tenen de la província de Lleida tendeix a ser fragmentada $i$ a repetir una sèrie d'aspectes clau, bastant similar en el conjunt de les quatre províncies catalanes. En aquest sentit sorprèn que, més enllà de diferències puntuals comentades al text, no hem trobat una sistemàtica diferenciació entre les visions dels estu- 
diants de la Universitat de Lleida i la dels estudiants de les altres universitats analitzades. Únicament la visió dels estudiants de la Universitat de Girona semblava ser més difusa. Ara bé, les diferències obtingudes entre universitats no permeten fixar cap patró de coneixement relacionat amb la distància.

En termes generals, la imatge que s'obté de la província de Lleida obeeix a un espai no urbanitzat (per molts, agrícola), amb un pes important dels Pirineus i la plana, i on només sobresortiria la ciutat de Lleida. Els Prepirineus, el relleu trencat de les Garrigues o la Segarra, així com tota activitat allunyada del sector primari, des del turisme a la informàtica, no formen la imatge mental que els estudiants catalans associen a Lleida.

Estem, per tant, davant d'una imatge mental del gruix dels estudiants catalans potent i interioritzada, però fragmentada i sense gaires matisos. Significativament, dins d'aquesta imatge, sobresurt el gran eix de comunicació de l'A-2, per on de ben segur ha transitat un bon nombre d'estudiants. Un element que reforçaria les teories vigents que apunten a una incorporació més facil en els mapes mentals dels espais viscuts. Aquesta visió, no obstant això, no és vàlida per a l'altra gran àrea representada: la Vall d'Aran, el Pallars Jussà i l'Alta Ribagorça. En aquest cas, la justificació més plausible a partir de les respostes obtingudes és la importància de la neu, o més ben dit, de les diverses estacions d'esquí. Així mateix, els nombrosos buits del mapa es corresponen en bona mesura a zones sense cap element destacat en la primera pregunta, fet que reforçaria aquesta noció de territoris «buits» per bona part dels estudiants catalans.

Un segon aspecte rellevant és que per la majoria d'estudiants de la província de Lleida, la província té les mateixes connotacions que pels estudiants de les altres províncies catalanes. Aquest fet hauria de portar a una reflexió sobre el grau de coneixement efectiu i l'autoestima que els mateixos ciutadans tenen de la seva província. Un tema complex, però que val la pena assenyalar ja que indicaria una certa pervivència del criticat "per Lleida ja està bé» (Claverol, Labernia i Reig, 1976).

Els dos aspectes comentats anteriorment són més evidents si tenim present que la majoria d'aspectes associats a la província no es localitzen en un punt concret. A mode exemple, resulta significatiu que malgrat la importància que es dóna a l'agricultura, pocs estudiants l'hagin situat en el mapa. No seria escabellat pensar que hi pogués aparèixer l'oli de les Garrigues, la pera de Lleida o el formatge de l'Alt Urgell i la Cerdanya, per dir algunes denominacions d'origen protegides de la província. Aquest fet reflecteix un desconeixement. La imatge genèrica existent porta a associar la província amb l'agricultura, però en realitat es desconeix pràcticament tot d'aquesta agricultura. Una situació que es deuria, en bona mesura, a l'escàs coneixement pràctic del territori per part de les persones analitzades.

En aquest sentit, la segmentació i el desconeixement que mostra la imatge del territori analitzat pot repercutir en aspectes diversos de l'activitat que s'hi desenvolupa. Per exemple, podem mencionar les dificultats que pot tenir una comarca com la Noguera per desenvolupar certes activitats entre un possible 
públic potencial que la desconeix, com mostren els resultats de Barcelona i Girona. Una situació que pot afectar aspectes al mateix territori: empreses tecnològiques que poden tenir dificultats per atreure professionals a una zona «agrícola», dificultats per vendre certs productes, ciutats que no resulten atractives per a la instal-lació de nous ciutadans, entre altres efectes.

Per últim, ens hem de plantejar fins a quin punt la situació descrita anteriorment pot tenir repercussions en la gestió del propi territori. Com ja apuntava Berque $(1994,17)$, la societat ordena el territori en funció de la interpretació que en fa, i viceversa. Existiria, així mateix, una diferenciació entre la visió del públic en general i la d'experts i professionals (per exemple, la proposta de Mendizàbal exposada a l'inici de l'article). En termes generals, aquests darrers tendirien a analitzar el territori de manera més fragmentària, incloent-hi més matisos, mentre que el conjunt de la ciutadania tindria una visió més de conjunt, que no sempre coincidiria amb l'anterior. Tenir present aquesta doble visió esdevé, per tant, fonamental per a una bona gestió del territori (Rogge et al., 2007: 160).

L'anàlisi desenvolupada obeiria més a la idea de públic general (o en tot cas, de futurs experts). En aquest sentit, els resultats permeten veure com, efectivament, la pluralitat d'actors, de funcions i d'interessos existents a la província de Lleida no sempre es reflecteix en el mapa mental dels estudiants. No podem deixar de plantejar-nos fins a quin punt el fet que bona part de la província tingui una imatge clarament agrícola pot acabar condicionant la gestió d'aquest espai, fins i tot en àmbits superiors. Un exemple podria ser prou il-lustratiu d'aquesta situació: dels set consellers encarregats de l'àrea d'Agricultura que ha tingut la Generalitat de Catalunya des del 1989 fins al 2015, sis eren de la província de Lleida ${ }^{8}$. Que un representant de Lleida ocupi la Conselleria d'Agricultura es veu normal. Ara bé, aquesta situació també pot actuar a la inversa, i dificultar que ocupi altres càrrecs.

Com hem observat, l'estudi de la imatge provincial permet corroborar la complexitat de l'àmbit i obtenir matisos importants, vàlids per plantejar algunes actuacions efectives. En aquest sentit, hem de ser conscients que la percepció d'un espai pot ser perdurable fins i tot a partir de l'experiència directa, tal com mostren les similituds de les imatges dels lleidatans i de la resta de catalans. Ara bé, aquest fet no hauria de ser un motiu vàlid per acceptar, des del territori, alguns dels fets exposats. Un bon treball de difusió podria generar noves imatges que facilitessin un millor coneixement de la província. Una situació que suposaria un major enriquiment personal tant de locals com de forans, però que també podria repercutir en un augment de l'autoestima de la població local, una millora de la comercialització dels productes de l'àrea, la creació de noves activitats econòmiques o la implantació de nous ciutadans en alguns dels seus nuclis.

8. Només un d'ells, Jordi William Carnes, no era de la província. Significativament, fou el que estigué menys temps al càrrec, set mesos. 


\section{Referències bibliogràfiques}

AldhuY, Julien (2004). «Imaginaire géographique, idéologie territoriale et production régionale: réexions autour des Landes de Gascogne (XVIIIème-XIXème)». Hégoa, 113-120.

Andressen, Curtis (1997). «Mental Maps of Asia: The Geographical Knowledge of Australian University Students». Asian Studies Review, 21 (1), 115-130. <http://dx.doi.org/10.1080/03147539708713144>

Antrop, Marc i van Eetvelde, Veerle (2000). «Holistic aspects of suburban landscape: visual image interpretation and landscape metrics». Landscape and Urban Planning, 50 (1-3), 43-58. $<$ http://dx.doi.org/10.1016/S0169-2046(00)00079-7>

ARRUDA, Ángela i ULUP, LiLIAN (2007). «Brasil imaginado: representaciones sociales de jóvenes universitarios». A: ARRUDA, Ángela i DE AlBA, Martha (coords.). Espacios imaginarios y representacions sociales. Rubí: Anthropos.

Auray, Jean Paul, Bailly, Antoine, Derycke, Pierre-Henry, Huriot, Jean-Marie (1994). Encyclopédie d'économie spatiale: Concepts - comportements - organisations. París: Economica.

Avendaño Arias, Johan Andrés (2014). «Representaciones territoriales sobre inseguridad y delincuencia en el espacio urbano de Bogotá: formas simbólicas de apropiación territorial». A: Bonastra, Quim; Vasconcelos P. Junior, Magno i TAPIA, Maricarmen (eds.). Actas del XIII Coloquio Internacional de Geocritica: El control del espacio y los espacios de control. Barcelona: Universitat de Barcelona.

Bédard, Mario; Augustin, Jean-Pierre i Desnoilles, Richard (dir.) (2011). L'imaginaire géographique. Perspectives, pratiques et devenirs. Quebec: Presses de l'Université du Quebec.

Berdoulay, Vincent (1985). «Les idéologies comme phénomènes géographiques». Cahiers de Géographie du Québec, 29, 205-216. $<\mathrm{http}: / / \mathrm{dx}$.doi.org/10.7202/021718ar>

Berque, Augustin (dir.) (1994). Cinq propositions pour une théorie du paysage. Seyssel: Champ Vallon.

Cameron, Duncan (1968). «A view point: the museum as a comunication system and implications for museums educations». Curator, 11 (1), 33-40. <http://dx.doi.org/10.1111/j.2151-6952.1968.tb00883.x>

CASTREE, Noel (2001). «Commodity fetishism, geographical imaginations and imaginative geographies». Environment and Planning A, 33 (9), 1519-1525. $<$ http://dx.doi.org/10.1068/a3464>

Chivallon, Christine (2008) . «L'espace, le réel et l'imaginaire: a-t-on encore besoin de la géographie culturelle?». Annales de géographie, 660-661 (2-3), 67-89. $<$ http://dx.doi.org/10.3917/ag.660.0067>

Claverol, Lluís; Labernia, Carles i Reig, Josep A. (1976). «El peso determinante del eslogan "per Lleida ja està bé"». CAU: construcción, arquitectura, urbanismo, 39, 90.

Cloke, Paul; Crang, Philip i Goodwin, Mark (1999). Introducing Human Geographies. Londres: Arnold.

De Alba, Martha (2009). Representaciones sociales y el estudio del territorio: aportaciones desde el campo de la psicología social. Cuajimalpa: Laboratorio de Análisis Socioterritorial, Universidad Autónoma Metropolitana.

Debarbieux, Bernard i Vanier, Martin (dir.) (2001). Ces territorialités qui se dessinent. La Tour d'Aigues: Editions de l'Aube. 
Di Méo, Guy i Buléon, Pascal (dir.) (2005). L'espace social. Lecture géographique des sociétés. París: Armand Colin.

Donatre, José Antonio i Galí, Núria (2011). «La imagen turística de Barcelona en la comunidad flickr». Cuadernos de Turismo, 27, 291-303.

Dupré, Sophie (2006). «Perceptions et représentations géographiques: un outil pour aménager les forêts touristifiées?». Théoros, 25 (2), 53-61.

Galí Espelt, Núria i Donaire Benito, José Antonio (2005). «The social construction of the image of Girona: a methodological approach». Tourism Management, 26, 777-785. <http://dx.doi.org/10.1016/j.tourman.2004.04.004>

Gilbert, Anne (1986). «L'idéologie spatiale: conceptualisation, mise en forme et portée pour la géographie». L'Espace géographique, 1, 57-66. <http://dx.doi.org/10.3406/spgeo.1986.4092>

Gökten, Cemil i Südaş Illkay (2014). «The Image of Australia: A Case Study on the Mental Maps of Turkish Immigrants in Sydney». Journal of Geography and Geology, 6 (2), 82-92. <http://dx.doi.org/10.5539/jgg.v6n2p82>

Greffe, Xavier (1999). La gestion du patrimoine culturel. París: Anthropos.

Gueben-Venière, Servane (2011). «En quoi les cartes mentales, appliquées à l'environnement littoral, aident-elles au recueil et à l'analyse des représentations spatiales?». EchoGéo, 17, 2-11. <http://dx.doi.org/10.4000/echogeo.12573>

Guerrero Tapia, Alfredo (2007). «Imágenes de América Latina y México a través de mapas mentales». A: Arruda, Ángela i de Alba, Martha (coords.). Espacios imaginarios y representacions sociales. Rubí: Anthropos.

Gumuchian, Hervé (1991). Représentations et aménagement du territoire. París: Anthropos.

Herrero Fabregat, Clemente (2008). «La ciudad como espacio construido y vivido por la persona». Contexto \& Educação, 79 (23), 129-154.

Ноттоla, Petri (2012). "Perceptions of the United States and the Americans. The collage approach». Finisterra, XLVII (93), 49-63.

KnEZ, Eugene I. i Wright, Gilbert (1970). «The museum as a communication system: an assessment of Cameron's viewpoint». Curator, 13 (3), 204-212. <http://dx.doi.org/10.1111/j.2151-6952.1970.tb00404.x>

Ledrut, Raymond (1973). Les images de la Ville. París: Ėditions Anthropos.

Lerivray, Bernard (1975). Guides bleus, guides vertes et lunettes roses. París: Du Cerf.

LYNCH, Kevin (1960). The Image of the City. Cambridge: The MIT Press.

Mackay, Kelly J. i Fesenmaier, Daniel R. (1997). «Pictorial element of destination image formation». Annals of Tourism Research, 24 (3), 537-565. <http://dx.doi.org/10.1016/S0160-7383(97)00011-X>

Marchand, Dorothée (2005). «La construction de l'image d'une ville: représentation de la centralité et identité urbaine». A: Robin, Monique i Ratiu, Eugénia (eds.). Transitions et rapports à l'espace. París: L'Harmattan, 299-335.

Martínez, Dolores (1996). «The tourist as deity: Ancient continuities in modern Japan». A: SElwyn, Tom (ed.). The tourist image. Myths and myth making in tourism. Chichester: Wiley, 163-178.

Massey, Doreen (2005). For Space. Londres: Sage.

Mc Kenna John; Quinn Rory J; Donnelly Daniel J. i Cooper J. Andrew G., (2008). "Accurate Mental Maps as an Aspect of Local Ecological Knowledge (LEK): a Case Study from Lough Neagh, Northern Ireland». Ecology and Society, 13, 1-23. 
Mendizàbal, Enric (1993). «Una proposta de model espacial per a la interpretació territorial de Catalunya». Treballs de la Societat Catalana de Geografia, 36 (VIII), 101-118.

Miossec, Jean-Marie (1977). «L'image touristique comme introduction à la géographie du tourisme». Annales de Géographie, 86 (473), 55-70. <http://dx.doi.org/10.3406/geo.1977.17568>

Musset, Alain (2010). Ciudad, sociedad, justicia: un enfoque espacial y cultural. Mar de la Plata: Universidad Nacional de Mar del Plata.

PAN, Bing i LII, Xiang (2011). «The long tail of destination image and online marketing». Annals of Tourism Research, 38 (1), 132-152. <http://dx.doi.org/10.1016/j.annals.2010.06.004>

Pinheiro, José de Queiroz (1998). «Determinants of cognitive maps of the world as expressed in sketch maps». Journal of Environmental Psychology, 18, 321-339. <http://dx.doi.org/10.1006/jevp.1998.0100>

Poutet, Hervé (1995). Images touristiques de l'Espagne: de la propagande politique à la promotion touristique. París: L'Harmattan.

Pritchard, Annette (2000). «Ways of seeing 'Them' and 'Us': tourism representation, race and identity». A: Robisno, Mike; Long, Philip; Evans, Nigel, Sharpley, Richard i Swarbrooke, John (eds.). Expressions of Culture, Identity and Meaning in Tourism. Sunderland: Business Education Publishers, 245-262.

Rogge, Elke; Nevens, Frank i Gulinck, Hubert (2007). «Perception of rural landscapes in Flanders: Looking beyond aesthetics». Landscape and Urban Planning, $82,159-174$. <http://dx.doi.org/10.1016/j.landurbplan.2007.02.006>

Roulier, Fréderic (2013). «Synthèses cartographiques des représentations mentales de l'espace».M@appemonde. Revue trimestrielle sur l'image géographique et les formes du territoire, 112. <http://mappemonde.mgm.fr/num40/index.html>

SAntos, Carla Almeida i Buzinde, Christine (2006). «Politics of identity and space: representational dynamics». Journal of Travel Research, 45 (3), 322-332.

Sassen, Saskia (2001). The Global City: New York, London, Tokyo. Princeton: Princeton University Press. <http://dx.doi.org/10.1515/9781400847488>

SMith, Andrew (2005). "Conceptualizing city image change: the re-imaging of Barcelona». Tourism Geographies, 7 (4), 398-423. <http://dx.doi.org/10.1080/14616680500291188>

Somoza MAdina, José (2006). La geografía de la percepción como instrumento de ayuda al planeamiento urbano. Biblioteca Virtual Miguel de Cervantes, <http://www. cervantesvirtual.com/nd/ark:/59851/bmc0v8s4>

StaszaK, Jean-François (2014). «Géographie et cinéma: modes d'emploi». Annales de Géographie 2014 (1-2), 695-696. <http://dx.doi.org/10.3917/ag.695.0595>

Tuan, Yi Fu (1977). Space and place: the perspective of experience. Minneapolis: University of Minnesota Press.

Vara Muñoz, José Luís (2008). "Cinco décadas de Geografía de la percepción». Ería, 77, 371-384. 